\title{
Pelvic Bone Metastases: Pattern and Distribution of 151 Cases
}

\author{
Koray Başdelioğlu' ${ }^{1}$ iD
}

${ }^{1}$ Istanbul Oncology Hospital, Orthopedics and Traumatology, Istanbul, Turkey

Koray BAŞDELIOĞLU, MD

İletişim: Koray Başdelioğlu Istanbul Oncology Hospital, Orthopedics and Traumatology, Istanbul, Turkey Tel: +905534045337

E-Posta: drkoraybasd@gmail.com

Gönderilme Tarihi : 07 Eylül 2020

\begin{abstract}
Purpose: The aim of this study is to examine the distribution properties of pelvic bone metastases according to primary cancers and to reveal the properties of additional bone metastases that may accompany pelvic bone metastasis.

Methods and Materials: 151 patients with pelvic bone metastases and without visceral metastases were included in the study. Clinical data, pathological diagnostic reports and PET-CT results of 151 patients were evaluated. The patients were evaluated in terms of age, gender, number of pelvic bone metastases (single focus, multiple foci) and localization of pelvic bone metastasis (sacroiliac joint, sacrum, ilium, ischium, pubis, acetabulum).

Results: Multiple pelvic metastasis frequency was significantly higher in the females $(80.00 \%)$ than in the males $(61.46 \%)(p=0.030)$. The most common location of the metastasis was the ilium for both genders. The most common location of the metastasis was ilium for the breast $(61.76 \%)$, prostate $(44.44 \%)$ and gynecologic $(66.67 \%)$ cancers. The most common locations of respiratory system cancer metastases were sacrum (54.29\%) and ilium (54.29\%). The acetabulum was the most common metastatic location for gastrointestinal (72.73\%) and urinary (58.33\%) tract cancers.

Conclusion: As the result of this study, the ilium is the most common metastatic bone region of the pelvis. Primary cancers often tend to cause multiple metastases to the pelvic bone. Evaluating the metastases of the pelvic ring with a larger number of cases may provide clues in finding the tumors of unknown primary origins.
\end{abstract}

Keywords: Pelvis, Pelvic bone, Bone, Metastases, Cancer, Unkown origin

Pelvis Kemik Metastazı: 151 olgunun paterni ve dağılımı

ÖZET

Amaç: Pelvis kemik halka, kemik metastazının en yaygın görüldüğü bölgelerinden biridir. Bu çalışmanın amacı pelvik halkayı oluşturan anatomik bölgelerin metastazlarını ve pelvis kemik metastazlarının primer kanserlere göre dağılım özelliklerini incelemek ve pelvis kemik metastazına eşlik edebilecek ek kemik metastazlarının özelliklerini ortaya koymaktır.

Yöntem: 2015-2019 yılları arasında İstanbul Onkoloji Hastanesinde kanser tanısı ile takip edilen hastaların verileri retrospektif olarak incelendi. Visseral organ metastazı olmadan pelvis kemik metastazı olan 151 hasta çalısmaya dahil edilme ve çalışmadan dışlanma kriterleri göz önünde bulundurularak çalışmaya dahil edildi. 151 hastanın klinik verileri, patolojik tanı raporları ve PET-BT sonuçları değerlendirildi. Hastalar yaş, cinsiyet, pelvis kemik metastaz sayısı (tek odak, çoklu odak) ve pelvik kemik metastazının (sakroiliak eklem, sakrum, ilium, ischium, pubis, asetabulum) lokalizasyonu açısından değerlendirildi.

Sonuçlar: Çalışmaya dahil edilen 151 hastanın ortalama yaşı $65.16 \pm 12.01$ (35-96)di. Çoklu pelvis kemik metastaz sıklı̆ı kadınlarda (\% 80.00) erkeklere (\% 61.46) göre anlamlı derecede yüksekti $(p=0.030)$. Metastazın en sık görüldüğü yer her iki cinsiyet için de ilium idi. Metastazın en sık yerleşim yeri meme (\% 61.76), prostat (\% 44.44) ve jinekolojik (\% 66.67) kanserler için ilium idi. Solunum sistemi kanseri metastazının en sık görüldüğğ yerler sakrum (\%54.29) ve ilium (\% 54.29) idi. Asetabulum gastrointestinal (\% 72.73) ve üriner (\% 58.33) sistem kanserleri için en yaygın metastaz bölgesiydi.

Çıkarım: Bu çalışmanın sonucu olarak ilium, pelvisin en yaygın metastatik kemik bölgesidir. Primer kanserler genellikle pelvik halkaya çoklu metastaz yapma eğilimindedir. Pelvik halkanın metastazlarının daha fazla sayıda vaka ile değerlendirilmesi primeri bilinmeyen tümörlerin bulunmasında ipuçları sağlayabilir.

Anahtar Kelimeler: Pelvis, Pelvik kemik, Kemik, Metastaz, Kanser, Bilinmeyen 
$\mathbf{T}$ he skeletal system is the most common distant metastasis region for malignant tumors $(1,2)$. In addition, bone metastasis is the most common cancer of bone (3). Lung, breast and prostate cancers are responsible for more than $80 \%$ of bone metastases (4). Bone metastasis can cause significant morbidity and affect prognosis $(5,6)$. The prognosis of patients with bone metastases varies depending on the primary cancer type, localization of the lesion and the presence of advanced metastasis (7). Severe bone pain, pathological fractures, spinal cord compression and hypercalcemia are important complications of bone metastases, and therefore bone metastasis is a threat to patients' well-being and quality of life (8-11).

The most common site of bone metastasis is the spine, followed by the pelvic bone. $(7,12)$. As with all bones, anatomical areas with high stress in the pelvis are particularly prone to pathological fractures (7). Enneking divided the pelvic ring into 4 parts according to the areas of the pelvis exposed to mechanical load (Figure 1) (13). Zone 1 and 3 are relatively non-weight bearing zone and zone 2 is exposed to high loads. Periacetabular (zone 2) lesions are at great risk for mechanical failure with progressive destruction of the hip joint. Metastatic lesions in zones 1 and 3 do not affect the mechanical stability of the pelvic ring, even if they are osteolytic (7). Although it is the 2 nd most common area of bone metastasis, to date there is no officially defined treatment algorithm for pelvic metastases $(7,12)$.

In the literature review, there was no study investigating the distribution pattern of pelvic bone metastases according to features of primary cancers. In this study, it was aimed to examine the metastases of the anatomical regions that make up the pelvic ring, to examine the distribution properties of pelvic bone metastases according to primary cancers and to reveal the properties of additional bone metastases that may accompany pelvic bone metastasis.

\section{Materials and Methods}

The data of patients who were followed up with the diagnosis of cancer in Istanbul Oncology Hospital between 2015-2019 were analyzed retrospectively. While 18F-fluoro-2-deoxyglucose (FDG) PET / CT performed, pelvic bone metastases, having complete data and contact information were determined as inclusion criteria, exclusion criteria were determined as the presence of more than one primary cancer, primary bone cancer and visceral metastases. Considering inclusion and exclusion criteria, 151 patients were included in the study.

Demographic features (age, gender), pathology reports of primary cancers and PET-CT results of 151 patients included in the study were retrospectively evaluated. Primary cancers were divided into 6 groups as respiratory system cancers (lung cancer, nasopharyngeal cancer), breast cancer, gastrointestinal tract cancers (gastric cancer, pancreatic cancer, colon cancer, rectum cancer), urinary tract cancers (renal cancer, bladder cancer), prostate cancer and gynecological cancers (endometrial cancer, cervical cancer, vagina cancer) (Table 1). The groups were evaluated in terms of age, gender, number of pelvic bone metastases (single focus, multiple foci) and localization of pelvic bone metastases. Pelvic bone metastases localization was categorized as sacroiliac joint, sacrum, ilium, ischium, pubis, acetabulum. In addition, additional bone metastases accompanying pelvic bone metastases were evaluated. Additional bone metastases were classified into six regions as the skull (cerebral cranium and facial cranium), spine (cervical spine, thoracic spine, lumbar spine), limb (humerus, radius, ulna, wrist, hand, femur, tibia, ankle, foot) and thoracic bones (ribs, sternum, clavicula, scapula). PET / CT results of 151 patients were analyzed for distribution and pattern of pelvic bone metastases and features of additional bone metastases of pelvic bone metastases.

All patients underwent FDG injection after 4-6 hours of fasting. PET / CT examination was performed 1 hour after FDG injection. General Electric Discovery IQ Gen 2 PET / CT device was used for the PET / CT of all patients. FDG uptake of lesions was evaluated as maximum standardized uptake value (SUVmax) in the images evaluated by 2 different nuclear medicine doctors who did not know the clinical features of the patients. Increased standardized uptake value (SUV) and osteoblastic lesions, osteolytic lesions, mixed osteoblastic/osteolytic lesions and without any significant anatomical changes in the CT image were evaluated as metastases.

The study protocol was approved by the Yeditepe University Ethics Committee. The study was carried out in accordance with the principles of the Helsinki Declaration. 


\section{Statistical Analysis}

All analyses were performed on SPSS v21 (SPSS Inc., Chicago, IL, USA). For the normality check, the KolmogorovSmirnov test was used. Data are given as mean \pm standard deviation for continuous variables and frequency (percentage) for categorical variables. Normally distributed variables were analyzed with the independent samples t-test or one-way analysis of variances (ANOVA) depending on the count of groups. Pairwise comparisons were performed with the Tamhane test. Categorical variables were evaluated by using the Chi-square tests or Fisher's exact tests. $p<0.05$ values accepted as statistically significant results.

\section{Results}

We included 151 patients ( 55 females and 96 males) in our study, the mean age was $65.16 \pm 12.01(35-96)$. Males were significantly older than the females $(p=0.009)$. The most common primer tumor type was respiratory system $(46.36 \%)$ tumors among all patients. The most common primer tumors of the females were breast $(56.36 \%)$, respiratory system (27.27\%) and gynecologic (10.91\%) tumors while the most common primer tumors of the males were respiratory system $(57.29 \%)$, prostate $(18.75 \%)$ and urinary tract $(11.46 \%)$ tumors $(p<0.001)$.

Multiple pelvic metastasis frequency was significantly higher in the females (80.00\%) than in the males (61.46\%) $(p=0.030)$. The most common location of the metastasis was the ilium for both genders. There were no significant differences between genders with regard to the location of metastasis (Figure 1). Fifty-two (94.55\%) female patients had other bone metastasis while $86(89.58 \%)$ male patients had other bone metastasis. The most common region of accompanying bone metastasis was the spine for both genders. There were no significant differences between genders with regard to accompanying other bone metastasis (Table 1).

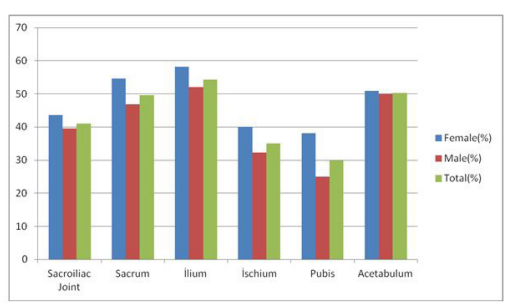

Figure 1- Pelvic ring metastasis rates according to gender
Table 1. Summary of patients and metastasis characteristics with regard to gender

\begin{tabular}{|l|c|c|c|c|}
\hline & $\begin{array}{c}\text { Female } \\
(n=55)\end{array}$ & Male $(n=96)$ & Total & $p$ \\
\hline Age & $61.82 \pm 13.17$ & $67.07 \pm 10.90$ & $65.16 \pm 12.01$ & 0.009 \\
\hline
\end{tabular}

Primary Cancer

\begin{tabular}{|l|c|c|c|}
\hline Breast & $31(56.36 \%)$ & $3(3.13 \%)$ & $34(22.52 \%)$ \\
\hline $\begin{array}{l}\text { Respiratory } \\
\text { System }\end{array}$ & $15(27.27 \%)$ & $55(57.29 \%)$ & $70(46.36 \%)$ \\
\hline Lung & $15(27.27 \%)$ & $53(55.21 \%)$ & $68(45.03 \%)$ \\
\hline Nasopharyngeal & $0(0.00 \%)$ & $1(1.04 \%)$ & $1(0.66 \%)$ \\
\hline Mesothelioma & $0(0.00 \%)$ & $1(1.04 \%)$ & $1(0.66 \%)$ \\
\hline $\begin{array}{l}\text { Gastrointestinal } \\
\text { Tract }\end{array}$ & $2(3.64 \%)$ & $9(9.38 \%)$ & $11(7.28 \%)$ \\
\hline Gastric & $2(3.64 \%)$ & $4(4.17 \%)$ & $6(3.97 \%)$ \\
\hline Pancreatic & $0(0.00 \%)$ & $1(1.04 \%)$ & $1(0.66 \%)$ \\
\hline Colonic & $0(0.00 \%)$ & $2(2.08 \%)$ & $2(1.32 \%)$ \\
\hline Rectal & $0(0.00 \%)$ & $2(2.08 \%)$ & $2(1.32 \%)$ \\
\hline Urinary Tract & $1(1.82 \%)$ & $11(11.46 \%)$ & $12(7.95 \%)$ \\
\hline Renal & $1(1.82 \%)$ & $2(2.08 \%)$ & $3(1.99 \%)$ \\
\hline Urinary Bladder & $0(0.00 \%)$ & $9(9.38 \%)$ & $9(5.96 \%)$ \\
\hline Prostate & $0(0.00 \%)$ & $18(18.75 \%)$ & $18(11.92 \%)$ \\
\hline Gynecologic & $6(10.91 \%)$ & $0(0.00 \%)$ & $6(3.97 \%)$ \\
\hline Ovarian & $2(3.64 \%)$ & $0(0.00 \%)$ & $2(1.32 \%)$ \\
\hline Endometrial & $1(1.82 \%)$ & $0(0.00 \%)$ & $1(0.66 \%)$ \\
\hline Cervical & $2(3.64 \%)$ & $0(0.00 \%)$ & $2(1.32 \%)$ \\
\hline Vaginal & $1(1.82 \%)$ & $0(0.00 \%)$ & $1(0.66 \%)$ \\
\hline Pelvic $)$ & \\
\hline
\end{tabular}

Pelvic Metastasis

\begin{tabular}{|l|l|l|l|l|}
\cline { 1 - 4 } Single & $11(20.00 \%)$ & $37(38.54 \%)$ & $48(31.79 \%)$ & \multirow{2}{*}{0.030} \\
\cline { 1 - 5 } Multiple & $44(80.00 \%)$ & $59(61.46 \%)$ & $103(68.21 \%)$ & \\
\cline { 1 - 5 } & & &
\end{tabular}

Location

\begin{tabular}{|l|c|c|c|c|}
\hline Sacroiliac joint & $24(43.64 \%)$ & $38(39.58 \%)$ & $62(41.06 \%)$ & 0.626 \\
\hline Sacrum & $30(54.55 \%)$ & $45(46.88 \%)$ & $75(49.67 \%)$ & 0.364 \\
\hline ilium & $32(58.18 \%)$ & $50(52.08 \%)$ & $82(54.30 \%)$ & 0.469 \\
\hline Ischium & $22(40.00 \%)$ & $31(32.29 \%)$ & $53(35.10 \%)$ & 0.340 \\
\hline Pubis & $21(38.18 \%)$ & $24(25.00 \%)$ & $45(29.80 \%)$ & 0.088 \\
\hline Acetabulum & $28(50.91 \%)$ & $48(50.00 \%)$ & $76(50.33 \%)$ & 0.914 \\
\hline $\begin{array}{l}\text { Accompanying } \\
\text { Metastasis }\end{array}$ & $52(94.55 \%)$ & $86(89.58 \%)$ & $138(91.39 \%)$ & 0.376 \\
\hline Spine & $48(87.27 \%)$ & $76(79.17 \%)$ & $124(82.12 \%)$ & 0.303 \\
\hline Extremity & $35(63.64 \%)$ & $48(50.00 \%)$ & $83(54.97 \%)$ & 0.105 \\
\hline Thorax & $40(72.73 \%)$ & $58(60.42 \%)$ & $98(64.90 \%)$ & 0.178 \\
\hline $\begin{array}{l}\text { Cranium \& } \\
\text { Maxillofacial }\end{array}$ & $9(16.36 \%)$ & $11(11.46 \%)$ & $20(13.25 \%)$ & 0.544 \\
\hline $\begin{array}{l}\text { Data are given as mean } \pm \text { standard deviation for continuous variables and as } \\
\text { frequency (percentage) for categorical variables }\end{array}$ \\
\hline \multicolumn{5}{|l|}{}
\end{tabular}

frequency (percentage) for categorical variables 
Patients with prostate tumors were significantly older than patients with breast, respiratory system, gastrointestinal tract and gynecologic tumors $(p<0.001)$. There were no significant differences between other tumor types with regard to age. Patients with breast tumors (82.35\%) and gynecologic tumors (83.33\%) had higher multiple metastasis percentages than the others, but this result was not found as significant ( $p=0.238$ ) (Figure 2 ) (Table 2 ).

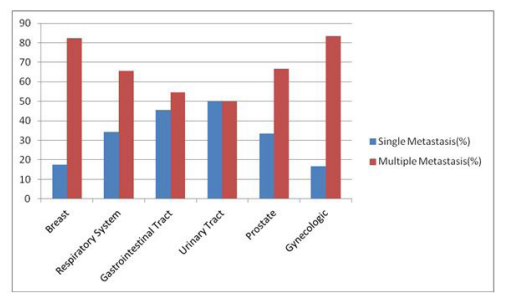

Figure 2- Number of pelvic bone metastasis according to primary cancer types

The most common location of the metastasis was the ilium for breast (61.76\%), prostate (44.44\%) and gynecologic (66.67\%) tumors. The most common locations of respiratory system tumor metastases were the sacrum (54.29\%) and ilium (54.29\%). The acetabulum was the most common metastasis location for gastrointestinal $(72.73 \%)$ and urinary $(58.33 \%)$ tract tumors.
Pubis metastasis percentage was significantly higher in the gastrointestinal tract (54.55\%) tumors than in the urinary tract (8.33\%) and respiratory system (21.43\%) tumors, additionally was significantly higher in the gynecologic $(50.00 \%)$ tumors than in the urinary tract (8.33\%) tumors $(p=0.047$ ) (Table 2) (Figure 3).

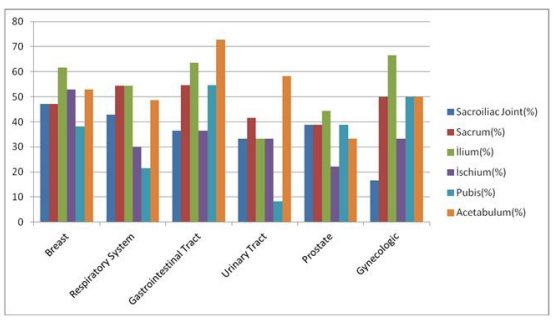

Figure 3- Pelvic ring metastasis rates according to primary cancer types

There were no significant differences between groups with regard to the location of metastasis. The spine was the most common accompanying other bone metastasis area for all tumor types except gynecologic tumors. All gynecologic tumors had metastases to the thorax. There were no significant differences between tumor types with regard to accompanying other bone metastasis (Table 2 ).

\begin{tabular}{|c|c|c|c|c|c|c|c|}
\hline & Breast $(n=34)$ & $\begin{array}{c}\text { Respiratory } \\
\text { System }(n=70)\end{array}$ & $\begin{array}{l}\text { Gastrointestinal } \\
\text { Tract }(n=11)\end{array}$ & $\begin{array}{l}\text { Urinary Tract } \\
\quad(n=12)\end{array}$ & $\begin{array}{l}\text { Prostate } \\
(n=18)\end{array}$ & $\begin{array}{l}\text { Gynecologic } \\
(n=6)\end{array}$ & $p$ \\
\hline Age & $62.85 \pm 14.71 \mathrm{a}$ & $64.27 \pm 10.09 \mathrm{a}$ & $58.36 \pm 12.31 \mathrm{a}$ & $72.25 \pm 9.09 \mathrm{ab}$ & $74.78 \pm 9.01^{b}$ & $58.00 \pm 8.15^{a}$ & $<0.001$ \\
\hline \multicolumn{8}{|l|}{ Pelvic Metastasis } \\
\hline Single & $6(17.65 \%)$ & 24 (34.29\%) & $5(45.45 \%)$ & $6(50.00 \%)$ & $6(33.33 \%)$ & $1(16.67 \%)$ & \multirow{2}{*}{0.238} \\
\hline Multiple & 28 (82.35\%) & 46 (65.71\%) & $6(54.55 \%)$ & $6(50.00 \%)$ & 12 (66.67\%) & $5(83.33 \%)$ & \\
\hline \multicolumn{8}{|l|}{ Location } \\
\hline Sacroiliac joint & $16(47.06 \%)$ & $30(42.86 \%)$ & $4(36.36 \%)$ & $4(33.33 \%)$ & 7 (38.89\%) & 1 (16.67\%) & 0.776 \\
\hline Sacrum & $16(47.06 \%)$ & $38(54.29 \%)$ & $6(54.55 \%)$ & $5(41.67 \%)$ & 7 (38.89\%) & $3(50.00 \%)$ & 0.858 \\
\hline Ilium & $21(61.76 \%)$ & 38 (54.29\%) & 7 (63.64\%) & $4(33.33 \%)$ & $8(44.44 \%)$ & $4(66.67 \%)$ & 0.500 \\
\hline Ischium & 18 (52.94\%) & $21(30.00 \%)$ & $4(36.36 \%)$ & $4(33.33 \%)$ & $4(22.22 \%)$ & $2(33.33 \%)$ & 0.229 \\
\hline Pubis & $13(38.24 \%) a b c$ & $15(21.43 \%)^{a b}$ & $6(54.55 \%)^{c}$ & $1(8.33 \%)^{a}$ & $7(38.89 \%)$ abc & $3(50.00 \%)$ bc & 0.047 \\
\hline Acetabulum & 18 (52.94\%) & 34 (48.57\%) & $8(72.73 \%)$ & 7 (58.33\%) & $6(33.33 \%)$ & $3(50.00 \%)$ & 0.444 \\
\hline Accompanying Metastasis & $33(97.06 \%)$ & $62(88.57 \%)$ & 10 (90.91\%) & $11(91.67 \%)$ & $16(88.89 \%)$ & $6(100.00 \%)$ & 0.730 \\
\hline Spine & $29(85.29 \%)$ & $59(84.29 \%)$ & $8(72.73 \%)$ & $9(75.00 \%)$ & $15(83.33 \%)$ & $4(66.67 \%)$ & 0.773 \\
\hline Extremity & $23(67.65 \%)$ & $33(47.14 \%)$ & $6(54.55 \%)$ & $5(41.67 \%)$ & $11(61.11 \%)$ & $5(83.33 \%)$ & 0.219 \\
\hline Thorax & $23(67.65 \%)$ & $43(61.43 \%)$ & 7 (63.64\%) & $5(41.67 \%)$ & $14(77.78 \%)$ & $6(100.00 \%)$ & 0.162 \\
\hline Cranium \& Maxillofacial & $6(17.65 \%)$ & $7(10.00 \%)$ & $2(18.18 \%)$ & $1(8.33 \%)$ & $3(16.67 \%)$ & $1(16.67 \%)$ & 0.857 \\
\hline
\end{tabular}




\section{Discussion}

Demographic features (age, sex), pathology reports of primary cancer and PET-CT results of 151 patients with pelvic bone metastasis without visceral organ metastasis were retrospectively analyzed. The pelvic ring was examined in anatomical regions as the sacroiliac joint, sacrum, ilium, ischium, pubis and acetabulum. Metastasis and distribution of primary cancers to the anatomical regions of the pelvic ring were examined. In addition, distribution characteristics of primary cancers in terms of pelvic bone metastasis focal number (single focus / multiple foci) were investigated.

In general, the most common involvement of the pelvic bone ring was the ilium, although it was not statistically significant, the ilium was the most common metastatic region in breast cancer (61.76\%), prostate cancer (44.44\%) and gynecological cancers (66.67\%); the sacrum (54.29\%) and ilium (54.29\%) were the most common metastatic regions in respiratory system cancers, acetabulum was the most common metastatic region in the gastrointestinal tract $(72.73 \%)$ and urinary tract cancers $(58.33 \%)$. While $68.21 \%$ of pelvic bone metastases constitute multiple metastatic foci, the rate of multiple metastatic foci in females was statistically significantly higher than in males (p:0.030). This may be due to the high incidence of breast cancers in women, and the gynecological cancers seen as a result of the study tend to have multiple metastases to the pelvic bone. When additional bone metastases were evaluated for pelvic bone metastases, the most common metastasis was the spine $(82.12 \%)$. The role of the vertebral venous plexus extending from the cranium to the spine and pelvis in the pathophysiology of metastasis may have caused this situation.

There are studies in the literature on general bone metastases and bone metastases of some cancers (14-18). However, there is no study examining the distribution and features of primary cancers in detailed in the anatomical areas of the pelvis. This study is the first study to reveal the metastasis and distribution of primary cancers into the pelvic bone ring by a detailed examination of the anatomy of the pelvis. Kakhki et al., in their study, 160 cancer patients were examined for general bone metastases and they emphasized that the region with the most common bone metastasis was the spine and the region with the second most common metastasis was the ribs and pelvis (14). In the study of Wang et al, they evaluated bone metastases of pulmonary and prostate cancer patients. They reported that pelvic, vertebral and thoracic bone involvements differ between the two cancers according to their metastasis. They stated that prostate cancer tends to metastasize to the vertebrae in the early stages and then to the thoracic bones, while pulmonary cancer is mostly random metastases (15). As the result of the study of Kawamura et al., the spine was the most common bone metastasis region in colorectal cancers. They also reported that right colon cancers tend to metastasize to long bones and left colon cancers to the spine mostly (16). In their studies evaluating the data of lung cancer patients, Zhang et al stated that the spine was the most common metastatic region in lung cancers, the second most common region was the scapula and ribs, and the third most common region was the pelvic bones (17). Wang et al. Also reported that prostate cancer most frequently metastasizes to the spine and pelvis in their study on patients with prostate cancer (17). The difference and unique feature of this study from other studies in the literature is that it reveals the distribution and properties of pelvic bone metastases made by primary cancers according to the detailed anatomical structure of the pelvic ring.

The most important limitation of the study is its retrospective structure. A greater number of breast and respiratory system cancers than other cancers can be considered as a limitation. It should be kept in mind that these cancers may be the most common cancers in the society. It should be taken into consideration that these cancers are the most common cancers in the society and can cause this condition. In addition, data on pathological fractures and the need for surgery could be added to the study. The effects of pelvic bone metastases on survival could be another criterion that can be evaluated. However, studies with a higher number of patients are needed for more objective results.

\section{Conclusion}

Although it varies according to the primary cancer type, in general, the ilium is the most common metastatic bone region of the pelvis. Primary cancers often tend to cause multiple metastases to the pelvic bone. Detailed examination of regions with complex anatomy such as the pelvic ring and spine in terms of metastasis features may provide important clues in the investigation of tumors of unknown primary origins.

Conflicts of interest statement

The authors declare that there are no conflicts of interest. 
Funding

The authors did not receive any outside funding, honorarium, grants or other forms of payment in support of their research for or preparation of this work.

\section{References}

1. Mundy GR. Metastasis to bone: causes, consequences and therapeutic opportunities, Nat. Rev. Cancer 2002;2:584-593 https:// doi.org/10.1038/nrc867.

2. Coleman RE. Metastatic bone disease: clinical features, pathophysiology and treatment strategies, Cancer Treat. Rev. 2001;27:165-176, https://doi.org/10.1053/ctrv.2000.0210.

3. Papagelopoulos PJ, Mavrogenis AF, Soucacos PN. Evaluation and treatment of pelvis metastases. Injury. 2007 Apr;38(4):509-520 https://doi.org/10.1016/j.injury.2007.01.008

4. Janjan N. Bone metastases: approaches to management. Semin Oncol 2001;28:28-34. DOI: 10.1016/s0093-7754(01)90229-5

5. Memon AG, Jaleel A, Aftab J. Patten of prostatic carcinoma metastases in bones detected by bone scans using Technitium $99 \mathrm{~m}$ methyl dipohsphate (Tc99m MDP) imaging technique. Pak J Med Sci 2006; 22: 180-183.

6. Morgan JWM, Adcock KM, Donohue RE. Distribution of skeletal metastases in prostatic and lung cancer. Urology 1990; 36: 31-34. doi: 10.1016/0090-4295(90)80308-a.

7. Müller DA, Capanna R. The Surgical Treatment of Pelvic Bone Metastases. Advances in Orthopedics. 2015. https://doi. org/10.1155/2015/525363

8. Mingyu Z, Xin L, Yuan Q, et al. Bone metastasis pattern of cancer patients with bone metastasis but no visceral metastasis. J Bone Oncol. 2019;Apr; 15: 100219. DOI: 10.1016/j.jbo.2019.100219

9. Boyce BF, Yoneda T, Guise TA. Factors regulating the growth of metastatic cancer in bone, Endocr. Relat. Cancer. 1999;6:333-347. DOI: $10.1677 /$ erc. 0.0060333

10. Rubens RD. Bone metastases - the clinical problem, Eur. J. Cancer.1998;34: 210-213. DOI: 10.1016/s0959-8049(97)10128-9

11. Yin JJ, Pollock CB, Kelly K. Mechanisms of cancer metastasis to the bone, Cell Res. 15 (2005) 57-62, https://doi.org/10.1038/ sj.cr.7290266.

12. Picci $P$, Manfrini $M$, Fabbri $N$ et al. Atlas of Musculoskeletal Tumors and Tumorlike Lesions, Springer, Berlin, Germany, 2014.

13. W. Enneking W, Dunham M, Gebhardt M, et al. A system for the classification of skeletal resections. La Chirurgia degli Organi di Movimento. 1990;75(1): 217-240.

14. Kakhki VRD, Anvari K, Sadeghi R, et al. Pattern and distribution of bone metastases in common malignant tumors. Nuclear Medicine Review 2013;;16(2): 66-69. DOI: 10.5603/NMR.2013.0037

15. Wang CY, Shen Y, Zhu SB. Distribution features of skeletal metastases: a comparative study between pulmonary and prostate cancers, Plos One 2015;10, https://doi.org/10.1371/journal.pone.0143437

16. Kawamura $H$, Yamaguchi $T$, Yano $Y$, et al. Characteristics and Prognostic Factors of Bone Metastasis in Patients With Colorectal Cancer. Dis Colon Rectum. 2018 Jun;61(6):673-678. doi: 10.1097/ DCR.0000000000001071.

17. Zhang L, Gong Z. Clinical Characteristics and Prognostic Factors in Bone Metastases from Lung Cancer. Med Sci Monit, 2017; Aug 24;23:4087-4094. DOI: $10.12659 / \mathrm{msm} .902971$

18. C. Wang, Y. Shen, Study on the distribution features of bone metastases in prostate cancer. Nucl. Med. Commun. 2012;33: 379383. DOI: $10.1097 /$ MNM.0b013e3283504528 